\title{
Early Acceptance of Renal Allografts in Mice Is Dependent on Foxp3 ${ }^{+}$Cells
}

\author{
Masahiro Miyajima, ${ }^{* \dagger}$ Catharine M. Chase ${ }^{\dagger}$ \\ Alessandro Alessandrini, ${ }^{\dagger \dagger}$ Evan A. Farkash, ${ }^{\neq}$ \\ Patricia Della Pelle, ${ }^{\ddagger}$ Gilles Benichou, ${ }^{* \dagger}$ \\ Jay A. Graham, ${ }^{*}$ Joren C. Madsen, ${ }^{* \dagger}$ \\ Paul S. Russell, ${ }^{* \dagger}$ and Robert B. Colvin ${ }^{\star \star \uparrow}$ \\ From the Transplantation Center,* the Pathology Service, ${ }^{\neq}$and \\ the Division of Cardiac Surgery, ${ }^{\S}$ Massachusetts General Hospital, \\ Boston; and the Departments of Surgery ${ }^{\dagger}$ and Pathology, ${ }^{\text {T }}$ \\ Harvard Medical School, Boston, Massachusetts
}

Mouse renal allografts have a remarkable ability to promote acceptance across full major histocompatibility complex incompatibilities in certain strain combinations without immunosuppression. The mechanism is unknown but is believed to involve immunoregulation. This study tests whether Foxp $3^{+}$T-regulatory cells are responsible in the early phase of graft acceptance, using B6.Foxp3 $3^{\text {DTR }}$ mice that express diphtheria toxin receptor (DTR) in Foxp $3^{+}$cells. The administration of DT to B6.Foxp $3^{\text {DTR }}$ recipients with accepted DBA/2 kidneys, 3 weeks to 3 months after transplantation, caused a marked depletion of Foxp 3 cells and triggered acute cellular rejection, manifested by a sudden increase in blood urea nitrogen within a week. None of the controls showed an increase in blood urea nitrogen, including DT-treated B6 wild-type recipients of DBA/2 kidneys or B6.Foxp $3^{\text {DTR }}$ recipients of isografts. Accepted DBA/2 allografts showed prominent lymphoid sheaths around arteries containing numerous $\mathrm{CD}^{+}{ }^{+}$Oxp $^{+}$cells, $\mathrm{CD}^{+}$ cells, dedritic cells, and $B$ cells, which was independent of CCR4. The lymphoid sheaths disintegrate after Foxp3 depletion, accompanied by widespread CD8 interstitial mononuclear inflammation, tubulitis, and endarteritis. The Foxp3 depletion caused an increased frequency of donor-reactive cells in the spleen by interferon (IFN) $\gamma$ enzyme-linked immunosorbent spot (ELISPOT) assays and increased expression of the maturation markers, CD86 and $\mathrm{IA}^{\mathrm{b}}$, on dendritic cells in the spleen and kidney. We conclude that Foxp $3^{+}$cells are needed to maintain acceptance of major histocompatibility complex-incompatible renal allografts in the first 3 months after transplantation and may act by inhibiting DC maturation. (Am J Pathol 2011, 178:1635-1645; DOI: 10.1016/j.ajpath.2010.12.024)

A long-standing goal of transplantation research is to discover clinically effective strategies to induce tolerance to major histocompatibility complex (MHC)-mismatched organ allografts. Striking success has been reported in some patients who received an $\mathrm{MHC}$-mismatched kidney after undergoing a complex conditioning regimen. ${ }^{1}$ Furthermore, a rare renal allograft recipient has achieved tolerance spontaneously and unpredictably. ${ }^{2}$ Further progress will benefit from understanding normal immune mechanisms that might be harnessed to promote graft acceptance.

Therefore, it is instructive to consider life-sustaining mouse renal allografts that in some MHC-mismatched strain combinations are accepted long-term without immunosuppression. ${ }^{3,4}$ In contrast, heart or skin grafts in the same donor-recipient combination are promptly rejected, as are kidneys in presensitized recipients. Most mice that had accepted kidneys also later accepted donor strain skin grafts for longer than 30 days (some for longer than a year), and third-party skin grafts were rejected, an indication of operational tolerance. Immunological tests revealed donor-reactive cells in the recipient and the transient appearance of alloantibody. Subsequent studies ${ }^{5-7}$ have confirmed that the kidney can induce systemic tolerance in certain other strain combinations, notably DBA/2 to B6. Acceptance was associated with transforming growth factor $\beta$-dependent immune regulation, suggesting a role for T-regulatory cells (Tregs). ${ }^{5}$ At 60 days after transplantation, recipient spleen cells had low reactivity to donor antigens in a delayed type hypersensitivity response, which was restored by blocking

Supported by a research award from the International Society for Heart and Lung Transplantation (M.M.) and grants from the NIH (R01HL07193205A11 to J.C.M.; R56AI081734 and RO1Al081734 to R.B.C.).

Accepted for publication December 13, 2010.

Supplemental material for this article can be found at http://ajp. amjpathol.org or at doi:10.1016/j.ajpath.2010.12.024.

Address reprint requests to Robert B. Colvin, M.D., Thier 831, Massachusetts General Hospital, Boston, MA 02114. E-mail: colvin@helix.mgh. harvard.edu. 
transforming growth factor $\beta$ but not IL-10. The transcription factor Foxp3, characteristic of Tregs, was increased in the renal allografts compared with isografts, as judged by RT-PCR and immunohistochemistry. Prominent infiltration of $\mathrm{Foxp}^{+}$cells occurred in the cortex-infiltrating tubules and eventually developed into nodular aggregates. ${ }^{5,7}$

Direct evidence for the importance of Foxp3 ${ }^{+}$cells for acceptance of other types of allografts comes from the adoptive transfer of Tregs $\left(\mathrm{CD} 4^{+} \mathrm{CD} 25^{+}\right)$, which promotes heart graft acceptance in settings of reduced donor reactivity [ie, recombination activating gene 1 $\left(\mathrm{RAG}^{-I-}{ }^{-}\right.$) recipients given few effector T cells]. ${ }^{8}$ The Tregs isolated from skin grafts after they have been accepted can promote graft acceptance in naïve recipients. ${ }^{9}$ Furthermore, acute and chronic rejection can be prevented by donor-stimulated Foxp $3^{+}$cells in recipients of $\mathrm{MHC}$-mismatched heart or skin grafts, provided the recipient has undergone sublethal irradiation. ${ }^{10}$ In this setting, it seems necessary that Foxp $3^{+}$cells have indirect reactivity to the donor. The Tregs may also be involved in some forms of tolerance induced by mixed chimerism ${ }^{11}$ or neonatal administration of donor cells. ${ }^{12}$

Despite this evidence, it has been difficult to prove that Tregs are responsible for allograft acceptance in MHCmismatched organs in immunocompetent recipients, in part because the standard method of depletion, antiCD25 (PC61), is neither complete nor specific. ${ }^{13-15}$ Depletion of $\mathrm{CD}_{25} 5^{+}$cells with antibody promotes graft rejection in certain specific situations, such as male skin to female recipients, bm12 hearts to $\mathrm{B} 6$ recipients, ${ }^{16}$ or B10 to $\mathrm{C} 3 \mathrm{H}$ liver allografts. ${ }^{17}$ In kidney grafts, the results were complicated by toxicity. ${ }^{7}$ However, new transgenic ${ }^{13}$ and knock-in ${ }^{14}$ strains for diphtheria toxin receptor (DTR) associated with Foxp3 expression on a C57/B6 background (B6.Foxp3 ${ }^{\text {DTR }}$ ) allow transient complete and specific depletion of Foxp3 ${ }^{+}$cells.

Therefore, we have directly addressed the question of the relevance of Foxp3 ${ }^{+}$cells to the spontaneous acceptance of mouse renal allografts using the B6.Foxp3 ${ }^{\text {DTR }}$ mouse as a recipient of fully $\mathrm{MHC}$-mismatched $\mathrm{DBA} / 2$ kidneys. Our findings point to a vital and necessary role for Foxp $3^{+}$cells in the maintenance of spontaneous graft acceptance and the formation of distinctive intragraft perivascular lymphoid structures.

\section{Materials and Methods}

\section{Mouse Strains}

The Foxp3 ${ }^{\text {DTR }}$ mice that have a knock-in of the coding sequence of DTR into the $3^{\prime}$ untranslated region of Foxp3 and green fluorescent protein were a gift. ${ }^{14}$ These mice were backcrossed to C57/B6 (B6) for several generations, and the presence of the transgene and wild-type (WT) Foxp3 mice was monitored by flow cytometry (green fluorescent protein) and PCR. ${ }^{14}$ Males hemizygous for the transgene (Foxp3 ${ }^{\mathrm{DTR}+/ y}$ ) were used in these experiments (herein designated B6.Foxp3 $3^{\mathrm{DTR}}$ ). The B6 and DBA/2 mice were obtained from Jackson Laboratories
(Bar Harbor, ME). The C-C chemokine receptor type 4 (CCR4) knockout mice on a B6 background were obtained from Andrew Luster, Massachusetts General Hospital, Boston. ${ }^{18}$ Mice were maintained in filter-top cages throughout the experiments, which were approved by the Massachusetts General Hospital Subcommittee of Research Animal Care.

\section{Treatment}

Renal transplantation was performed with simultaneous bilateral recipient nephrectomies. ${ }^{3}$ Renal function was monitored by blood urea nitrogen (BUN) at least weekly. ${ }^{3}$ At 3 to 12 weeks after transplantation, when renal function was stable and BUN was in the normal range (20 to 40 $\mathrm{mg} / \mathrm{dL}$ ), blood was obtained for alloantibody determination and Foxp3 levels. The recipients were then randomly selected to receive either $50 \mu \mathrm{g} / \mathrm{kg}$ of DT in $200 \mu \mathrm{L}$ of water or vehicle i.p. on two consecutive days. The DT stocks were frozen, thawed once, and diluted to $5 \mu \mathrm{g} / \mathrm{mL}$ in water according to the manufacturer's protocol (Sigma Chemicals, St. Louis, MO). Four renal transplant groups were compared: DBA/2 to B6.Foxp3 ${ }^{\text {DTR }}$ given DT $(n=9)$, DBA/2 to B6.Foxp3 ${ }^{\text {DTR }}$ given vehicle or no treatment $(n=$ 3), DBA/2 to B6WT given DT $(n=6)$, and B6.Foxp3 ${ }^{\mathrm{DTR}}$ to B6.Foxp3 ${ }^{\text {DTR }}$ given DT $(n=4)$. Animals were euthanized when the BUN was greater than $100 \mathrm{mg} / \mathrm{dL}$ or when they appeared ill, with the paired controls taken at the same time. The Foxp3 levels were assessed on peripheral blood by flow cytometry (FACScan; BD Biosciences, San Jose, CA) using $1.0 \mathrm{mg} / \mathrm{mL}$ Alexa fluor-conjugated antimouse Foxp3 and anti-CD4 for 30 minutes at $4^{\circ} \mathrm{C}$ (BD Pharmingen, San Diego, CA). Cells were permeabilized by buffer containing Igepal CA-630 (Sigma).

\section{Histological and Immunopathological Features}

Sagittal sections of allografts were fixed in formalin, and sections were stained for $\mathrm{H}$ and $\mathrm{E}$; PAS sections were scored according to Banff criteria. ${ }^{19}$ All arteries present in two full sagittal sections of the kidney were scored for endarteritis (mean $16.5 \pm 4.4$; range, 11 to 25). Other organs (ie, heart, liver, lung, intestine, stomach, submandibular gland, pancreas, brain, spleen, thymus, and lymph nodes) were examined for evidence of autoimmunity. Sections were stained for Foxp3 (JK-16S; eBiosciences, San Diego, CA) and CD3 (Polyclonal DAKO; DAKO, Carpinteria, CA), using a double stain, and counted as previously described. ${ }^{6}$ A separate portion was frozen for immunofluorescence and stained for C4d. ${ }^{20}$ Other stains included CD4 (GK1.5; BD Pharmingen), CD8 (Santa Cruz Biotechnology, Santa Cruz, CA), F4/80 (AbD Serotec, Raleigh, NC), CD11c (hamster; AbD Serotec), CD86 (GL-1; BioLegend, San Diego, CA), and CD19 (Beckman Coulter, Brea, CA). Light microscopic imaging was performed with a microscope (Eclipse 50i; Nikon, Tokyo, Japan) equipped with a digital camera (Spot RT KE; Diagnostics Instruments, Sterling Heights, $\mathrm{MI})$. Whole slide scans were performed at a magnification of $\times 20$ with a doubler on a microscope (Aperio CS; Aperio, Vista, CA). Digital photomicrographic images 
were processed using a computer program (Adobe Photoshop).

\section{Assessment of Intragraft DCs}

Cryostat whole cross sections of allografts were stained for CD86 (rat anti-CD86, biotinylated rabbit anti-rat IgG, and Alexa 488-conjugated streptavidin) and then CD11c (hamster anti-Cd11c, biotinylated goat antihamster IgG, and Cy3-strepavidin), using normal rabbit or goat serum and avidin as blocking agents between steps. Slides were scanned at constant illumination in a fluorescence digital slide scanner ( $\mathrm{Na}$ noZoomer Digital Pathology, Hamamatsu Photonics KK, Bridgewater, NJ), equipped with filters (DA/FI/ TX-B; Semrock), using a $\times 40$ objective and $\times 8$ gains on the red and green channels and the exposure time. Ten random $\times 200$ high-power fields (total area, 0.101 $\mathrm{mm}^{2} ; 7,864,320$ pixels) in areas free of artifacts (folds and prominent autofluorescence) were captured using NDP.view (Hamamatsu Photonics KK) and analyzed using ImageJ version 1.42 (http://rsbweb.nih.gov/ij). The total number of pixels with intensity greater than 60 in the red channel $\left(\mathrm{CD} 11 \mathrm{c}^{+}\right) / \mathrm{mm}^{2}$ was plotted against pixels with intensity greater than 60 in both red and green channels $\left(\mathrm{CD} 11 \mathrm{c}^{+} \mathrm{CD} 86^{+}\right) / \mathrm{mm}^{2}$. The DCs averaged 294 \pm 108 red pixels per cell cross section with this technique (an average of 10 measurements); however, pixel counts are not reliably converted into cell number (mean $\pm \mathrm{SD}$ ).

\section{Isolation of CD11C ${ }^{+}$Cells from Spleen and Kidney}

Spleens and kidneys were obtained from B6.Foxp3 ${ }^{\text {DTR }}$ mice 7 days after they were treated with $50 \mu \mathrm{g} / \mathrm{kg}$ of DT i.p. on two consecutive days. The DCs were isolated from suspensions prepared by sieving (spleen) or collagenase digestion (kidney) ${ }^{21}$ using $\mathrm{CD}_{11 \mathrm{C}^{+}}$selection magnetic cell beads and separation columns (Miltenyi Biotec, Auburn, CA). Cells were stained with anti-CD86-PE-conjugated antibodies (clone GL-1; eBioscience) or anti-I $\mathrm{A}^{\mathrm{b}}$ (clone AF6-120.1; BD Pharmingen), and 10,000 cells were analyzed by scanning (FACScan) using software (CellQuest Pro).

\section{Antibody Assays}

Donor-specific antibody was determined by flow cytometry using mouse thymocytes as targets; results are presented as mean fluorescence channel. ${ }^{20,22}$ Third-party controls were B10.BR $\left(\mathrm{H}-2^{\mathrm{k}}\right)$.

\section{ELISPOT Assays}

The ELISPOT assays for IFN- $\gamma$ were performed by standard techniques. The ELISPOT plates (MultiScreen ${ }_{\text {HTS }}$ IP Sterile Plate; Millipore, Billerica, MA) were coated overnight with anti-IFN- $\gamma$ capture antibodies (BD Pharmingen) at $4 \mu \mathrm{g} /$ $\mathrm{mL}$. A total of $1.25 \times 10^{5} \mathrm{~T}$ cells enriched from spleen cell suspensions were placed in each well with or without donor or self-stimulator cells and cultured for 24 hours at $37^{\circ} \mathrm{C}$ in five percent $\mathrm{CO}_{2}$. Biotinylated anti-IFN- $\gamma$ antibodies were added overnight at $2 \mu \mathrm{g} / \mathrm{mL}$ and detected with avidin-horseradish peroxidase and 3-amino-9-ethylcarbazole. Plates were scored on a computer-assisted ELISPOT reader (ImmunoSpot S5 Core Analyzer; Cellular Technologies, Ltd, Cleveland, OH). Data are expressed as positive clones $/ 10^{6} \mathrm{~T}$ cells.

\section{Data Analysis}

Graft rejection was defined as graft dysfunction accompanied by pathological features of cellular or humoral rejection, according to the Banff 2007 criteria, $^{19}$ and not attributable to other lesions, such as obstruction or infection. Quantitative differences among multiple groups were assessed by one-way analysis of variance (Dean AG, Sullivan KM, Soe MM, http://www.OpenEpi.com, last accessed June 2, 2011). For comparisons of two groups, the allograft control groups (WT B6 given DT and Foxp3 ${ }^{\text {DTR }}$ not given DT) were combined and compared with the Foxp3 ${ }^{\text {DTR }}$ group given DT, using the Student's $t$-test and the Mann-Whitney U-test. All aggregate data in the text are mean $\pm S D$.

\section{Results}

\section{DT-Mediated Foxp3 Depletion in Foxp3 ${ }^{\text {DTR }}$ Mice}

As reported, ${ }^{14}$ the administration of $50 \mu \mathrm{g} / \mathrm{kg}$ DT on two successive days to normal B6.Foxp3 ${ }^{\text {DTR }}$ caused a rapid loss of $\mathrm{Foxp}^{+}$cells from the blood, which returned to normal levels by 10 to 15 days (see Supplemental Figure S1A at $h$ ttp://ajp.amjpathol.org). Depletion of Foxp3 ${ }^{+}$cells was evident in the thymus, spleen, and lymph nodes by immunohistochemistry at 2 days after DT, as previously quantitated by flow cytometry with the same dose schedule. ${ }^{14}$ The treatment was well tolerated, with no weight loss, change in behavior, overt signs of autoimmune disease, or effect on renal histological features or function (BUN) (see Supplemental Figure S1B at http://ajp. amjpathol.org). Other organs showed no pathological features, aside from transient focal inflammation in the liver and pancreas on day 6 , which disappeared by day 24 to 50 (data not shown).

\section{Foxp3 Depletion Causes Acute Allograft Dysfunction}

The DT (50 $\mu \mathrm{g} / \mathrm{kg}$ ) was given on two successive days to nine B6.Foxp3 ${ }^{\text {DTR }}$ recipients of DBA/2 kidneys that had stable renal function 3 to 12 weeks after transplantation $(49 \pm 25$ days, mean \pm SD). A marked, but transient, decrease in blood Foxp3 ${ }^{+}$cells occurred, similar to B6.Foxp3 ${ }^{\text {DTR }}$ without transplants (see Supplemental Figure S1A at $h$ ttp://ajp.amjpathol.org). Four to seven days after the first dose of DT, the BUN increased in each recipient (Figures 1 and 2), independent of the time after transplantation. In contrast, none of the controls studied at similar intervals (55 \pm 28 days) after transplantation 
A

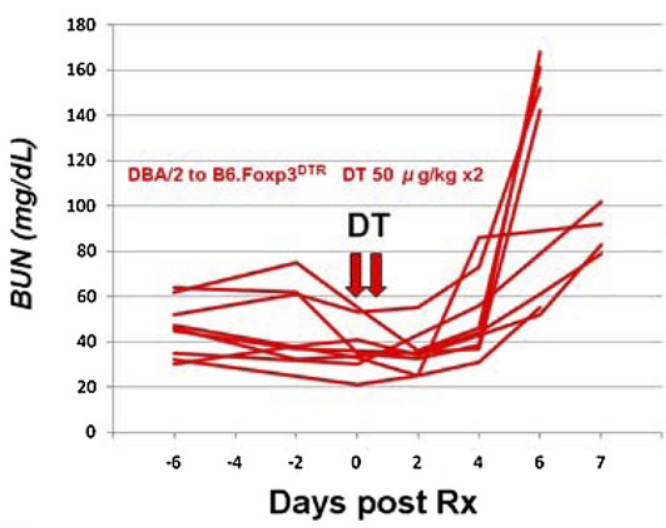

B

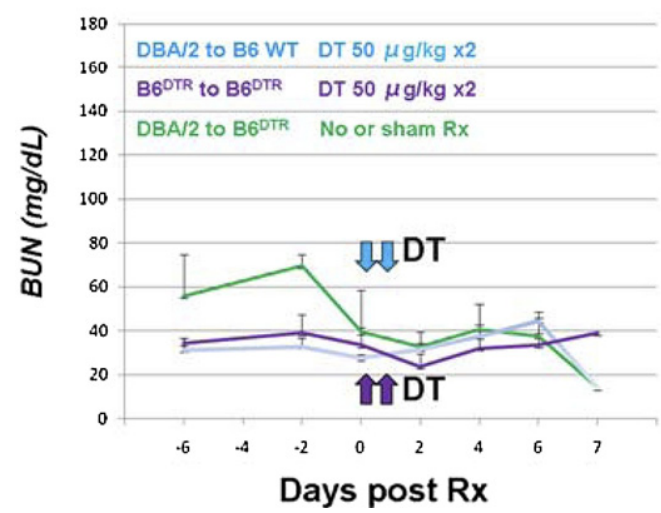

Figure 1. A: Time course of BUN in response to DT in individual B6.Foxp $3^{\text {DTR }}$ recipients of $\mathrm{DBA} / 2$ allografts (red lines; $n=9$ ). All B6.Foxp $3^{\text {DTR }}$ mice that received DT developed acute rejection and an increase in BUN 6 to 7 days after DT. B: Time course of BUN, plotted as mean $\pm \mathrm{SD}$ in controls, including $\mathrm{B} 6 \mathrm{WT}$ recipients of DBA/2 allografts that received DT (blue line; $n=6$ ), B6.Foxp $3^{\mathrm{DTR}}$ recipients of isografts that received DT (purple line; $n=4$ ), and B6.Foxp $3^{\text {DTR }}$ recipients of DBA/2 allografts that were randomized to vehicle or no treatment (green line; $n=$ 3). No significant change in BUN was observed.

showed an increase in BUN, including three B6.Foxp3 ${ }^{\text {DTR }}$ recipients of $\mathrm{DBA} / 2$ kidneys given vehicle or no treatment, six B6WT recipients of DBA/2 kidneys given DT, and four B6.Foxp3 ${ }^{\text {DTR }}$ recipients of B6.Foxp3 ${ }^{\text {DTR }}$ isografts given DT (Figures 1 and 2). There was no difference between the controls given vehicle or no treatment. The BUN increased from $36 \pm 11$ to $115 \pm 41$ $\mathrm{mg} / \mathrm{dL}$ in the nine DT-treated B6.Foxp3 ${ }^{\mathrm{DTR}}$ recipients of allografts and increased from $33 \pm 7$ to $39 \pm 7 \mathrm{mg} / \mathrm{dL}$ in nine controls (WT plus DT and non-DT treated mice), a change of $80 \pm 38$ vs $6 \pm 11 \mathrm{mg} / \mathrm{dL}$, respectively $(P<$ 0.001 , $t$-test; and $P<0.0003$ Mann-Whitney U-test, respectively) (Figure 2). Isografts showed no significant change in BUN ( $6 \pm 4 \mathrm{mg} / \mathrm{dL})$. The four groups were significantly different when analyzed by analysis of variance $(P=0.0001)$.

\section{Stable Allografts Have Treg-Rich Organized Lymphoid Structures}

The B6.Foxp3 ${ }^{\mathrm{DTR}}$ recipients of DBA/2 kidneys given vehicle or no treatment and B6 WT given DT showed
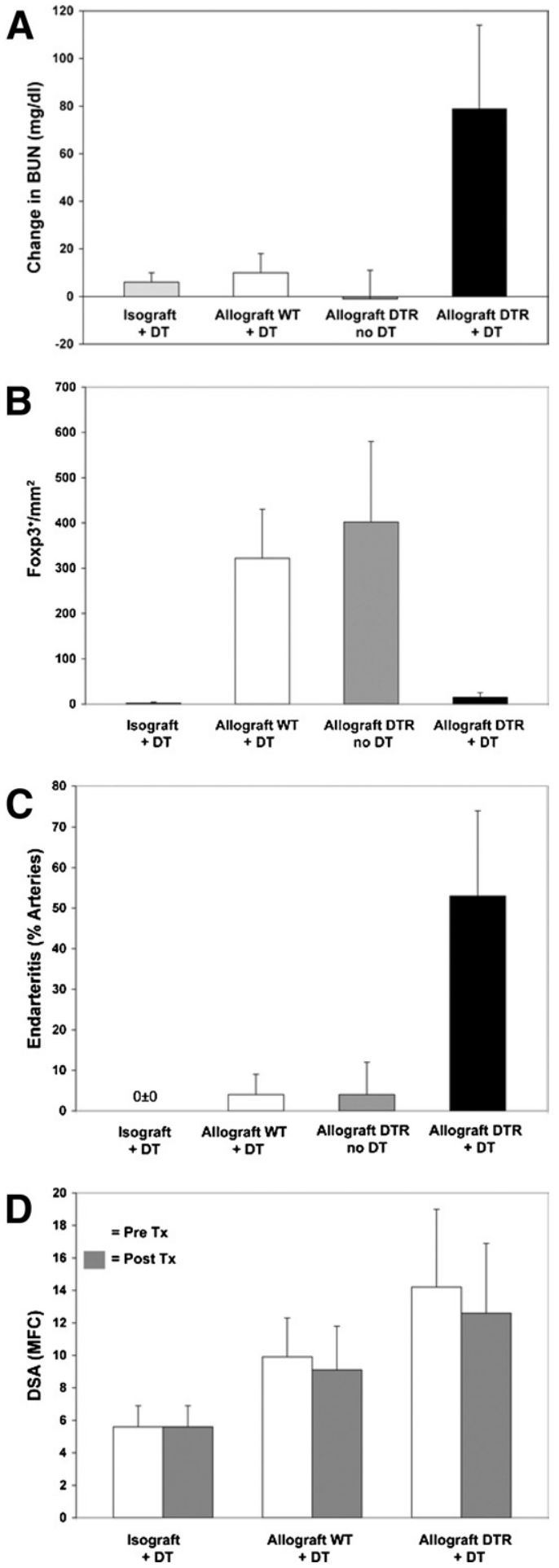

Figure 2. The BUN response (A), Foxp3 depletion (B), endarteritis $(\mathbf{C})$, and donor-reactive antibody $(\mathbf{D})$ levels in the four groups studied: B6.Foxp $3^{\text {DTR }}$ recipients of B6.Foxp $3^{\text {DTR }}$ isografts that received DT (Isograft+DT), B6 WT recipients of $\mathrm{DBA} / 2$ allografts that received DT (Allograft WT+DT), B6.Foxp $3^{\text {DTR }}$ recipients of DBA/ 2 allografts that did not receive DT (Allograft DTR no DT), and B6.Foxp $3^{\text {DTR }}$ recipients of DBA $/ 2$ allografts that received DT (Allograft DTR+DT). The last group had a significantly greater increase in BUN (A), a lower Foxp3 ${ }^{+}$cell count $/ \mathrm{mm}^{2}(\mathbf{B})$, and a higher percentage of arteries with endarteritis $(\mathbf{C})$ than did the two allograft control groups combined (all: $P<0.001, t$-test; and $P<0.0001$, Mann-Whitney $U$-test). One-way analysis of variance of the four groups in $\mathbf{A}, \mathbf{B}$, and $\mathbf{C}$ also showed significant differences $(P \leq 0.001)$. No significant changes in antibody levels were detected $\mathbf{D}$. Tx indicates treatment 

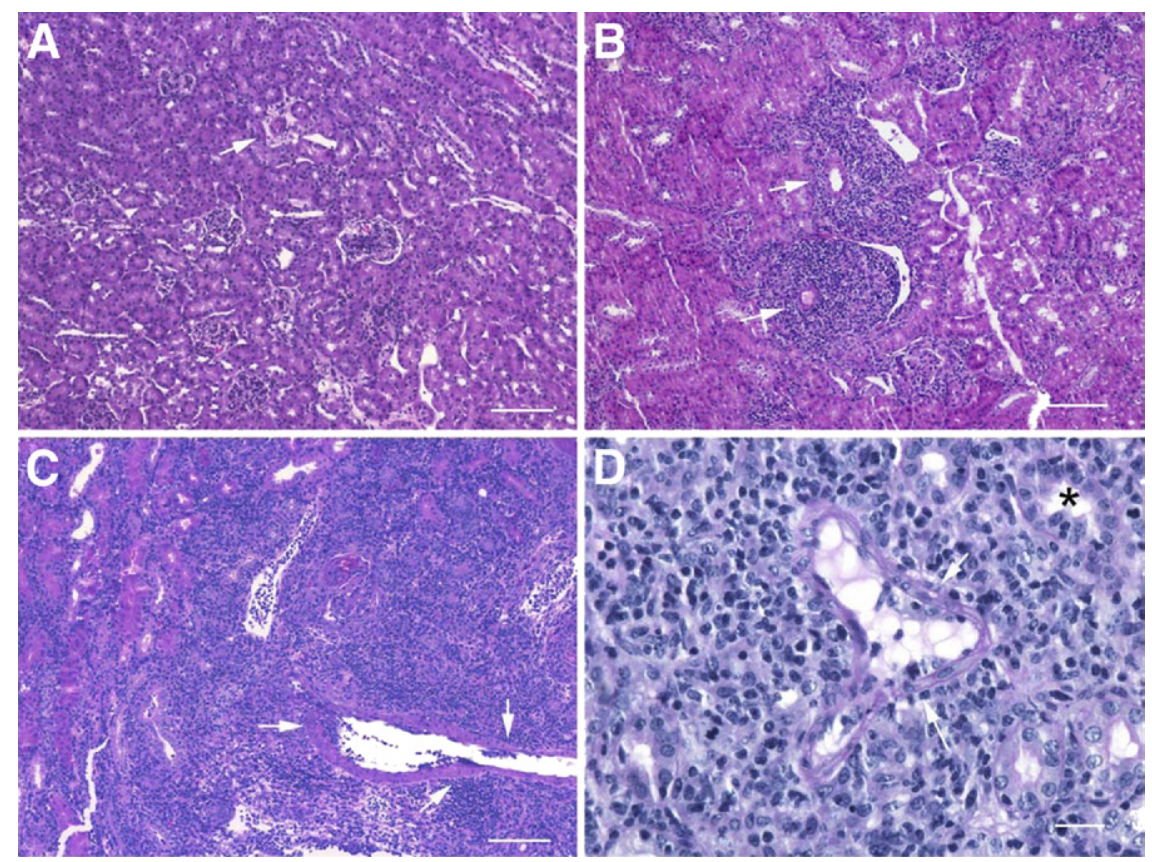

Figure 3. Representative pathological features of transplanted kidneys. A: Control isograft kidney in a B6.Foxp $3^{\text {DTR }}$ recipient given DT. No infiltrate or other abnormality is evident (arrow on artery). B: Control DBA/2 allograft kidney in a B6.Foxp $3^{\text {DTR }}$ recipient given vehicle. The infiltrate is primarily nodular and periarterial (arrows on arteries), forming TOLS, characteristic of accepted grafts. C: The DBA/2 allograft kidney in a B6.Foxp3 DTR recipient 7 days after treatment with DT. In $\mathbf{C}$, an intense, diffuse, interstitial mononuclear infiltrate is present; an arcuate artery showed florid endarteritis (arrows), features typical of acute cellular rejection (D). Higher power of a DBA/2 kidney in a B6.Foxp $3^{\text {DTR }}$ recipient after DT treatment shows arteritis (arrows), and a diffuse mononuclear infiltrate and tubulitis (asterisk). Scale bars: 100 $\mu \mathrm{m}(\times 100 ; \mathrm{H}$ and $\mathrm{E} ; \mathbf{A}-\mathbf{C}) ; 20 \mu \mathrm{m}$ (PAS; D). prominent infiltrates of $T$ cells around the cortical arteries, as previously noted ${ }^{6}$ (Figure 3 ). These T cells formed a longitudinal sheath around the arteries that appeared nodular in cross section and contained many $\mathrm{CD}^{+} \mathrm{Foxp}^{+}$cells (Figure 4), herein termed Treg-rich organized lymphoid structures (TOLS). The
TOLS consisted primarily of $\mathrm{CD}^{+}$cells (Figure 4) intermixed with B cells $\left(\mathrm{CD} 19^{+}\right)$and DCs $\left(\mathrm{CD} 11 \mathrm{C}^{+}\right)(\mathrm{Fig}-$ ure 5). The T cells were predominately $\mathrm{CD} 4^{+}$, with rare $\mathrm{CD}^{+}$cells (Figure 6). Macrophages $\left(\mathrm{F} 4 / 80^{+}\right)$were largely restricted to the periphery (data not shown). The TOLS persisted throughout the sampling period.

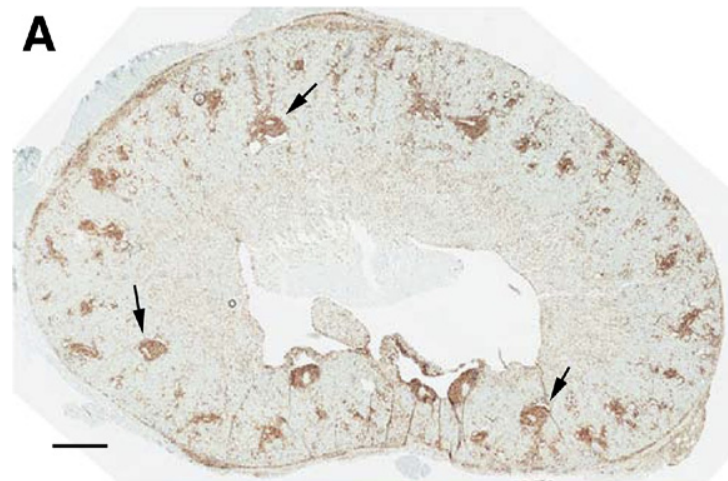

B
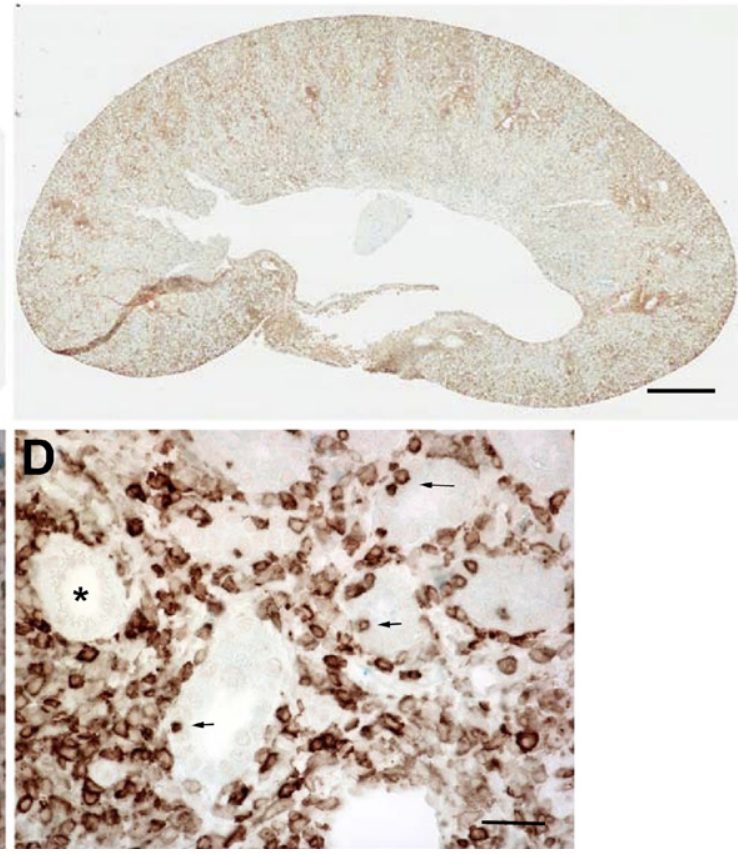

Figure 4. The DBA/2 renal allografts in B6.Foxp $3^{\text {DTR }}$ recipients on day 28. Sections stained with antibodies to CD3 (brown) and Foxp3 (blue). A and C: Untreated recipient. B and D: Recipient treated 7 days previously with DT. A: The characteristic periarterial sheath of T cells (TOLS) that appears nodular in the cross section is evident in the control graft (arrows). B: The nodular pattern is largely lost after DT treatment and T cells infiltrate diffusely in the cortex. A higher magnification reveals abundant periarterial Foxp $3^{+}$cells (blue) in the TOLS of the control (C), but not the DT-treated, recipient (D). The asterisk indicates arteries. In $\mathbf{D}$, the infiltrate extends into the cortex and tubulitis is evident (arrows). Aperio scans of whole kidney cross sections are shown in $\mathbf{A}$ and $\mathbf{B}$. Scale bars: 1 mm (A and B); $25 \mu \mathrm{m}$ (C and D). 

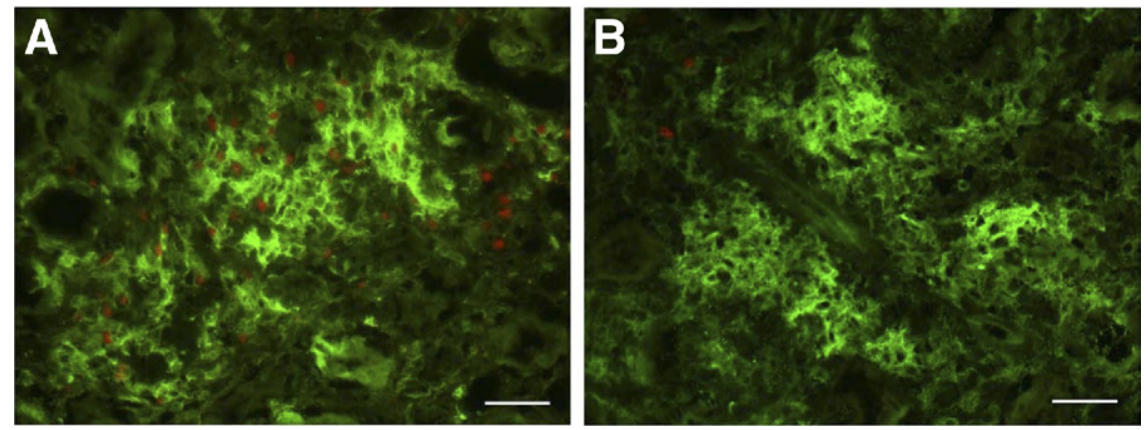

Figure 5. Immunofluorescence stains for Foxp3 (red) and $\mathrm{CD} 11 \mathrm{c}$ (green) in the perivascular infiltrates of DBA/2 kidney allografts. A: The nodular infiltrate in a B6.Foxp $3^{\text {DTR }}$ mouse control treated with vehicle (1699) shows abundant Foxp $^{+}$cells in close association with $\mathrm{CD} 11 \mathrm{c}^{+}$ DCs. B: The $\mathrm{CD}_{11 \mathrm{C}^{+}}$DCs remain in the perivascular area in a B6.Foxp $3^{\mathrm{DTR}}$ mouse treated with DT (1713), but the Foxp $3^{+}$cells are almost entirely eliminated. Dual-color immunofluorescence merged images are shown. Scale bars: 25 $\mu \mathrm{m}$ for the cryostat sections.

There was typically minimal or no evidence of rejection histologically, but occasional tubulitis and arterial inflammation were noted. The CD4 and CD8 cells were sparse in the cortex; C4d was present diffusely in the peritubular capillaries in $75 \%$ of the control allografts. There was no difference in the pathological features of the kidney between those with and without C4d deposition and no features indicative of antibody-mediated rejection, such as intracapillary neutrophils, glomerulitis, or mononuclear cells.

Isografts in B6.Foxp3 ${ }^{\text {DTR }}$ recipients given DT showed minimal changes (Figure 2), with rudimentary or no aggregates of lymphocytes around arteries and rare Foxp3 $^{+}$cells. No evidence of rejection was seen (no interstitial inflammation, tubulitis, glomerulitis, arteritis, or C4d deposition).

\section{Foxp3 Depletion Causes Disintegration of Perivascular TOLS and Acute Cellular Rejection}

The B6.Foxp3 ${ }^{\text {DTR }}$ recipients of DBA/2 kidneys given DT showed widespread mononuclear interstitial infiltrates and tubulitis and prominent endarteritis, typical of acute cellular rejection, Banff type 2 (Figure 2). Quantitation of the arteritis showed a significant difference between the groups, with the experimental group (DTtreated B6.Foxp3) having $53 \% \pm 21 \%$ of the arteries affected vs $4 \% \pm 5 \%$ in the combined allograft control groups $(P<0.001$, $t$-test; and $P<0.0002$, Mann-Whitney $U$-test; Figure 2). The four groups were significantly different by analysis of variance $(P<0.0001)$. Depletion of Foxp $3^{+}$cells was accompanied by a prominent increase in the diffuse infiltrate in the cortex of $T$ cells, with partial disintegration of the nodular pattern (Figure 4). The diffuse infiltrate was composed of CD8 and CD4 cells (Figure 6). The Foxp $3^{+}$cells were markedly reduced in the allografts (Figures 4 and 6), averaging $15 \pm 10 / \mathrm{mm}^{2}$, compared with $349 \pm 156 / \mathrm{mm}^{2}$ in control allografts combined $(P<0.001$, $t$-test; and $P<0.0001$, Mann-Whitney $U$-test). An analysis of variance for the four groups also showed significant differences $(P<0.0001)$. There was no change in the distribution or number of $\mathrm{B}$ cells in the allografts after Foxp3 depletion (306 $\pm 206 / \mathrm{mm}^{2}$ vs $299 \pm 199 / \mathrm{mm}^{2}$ for control vs Foxp3 depleted). B cells
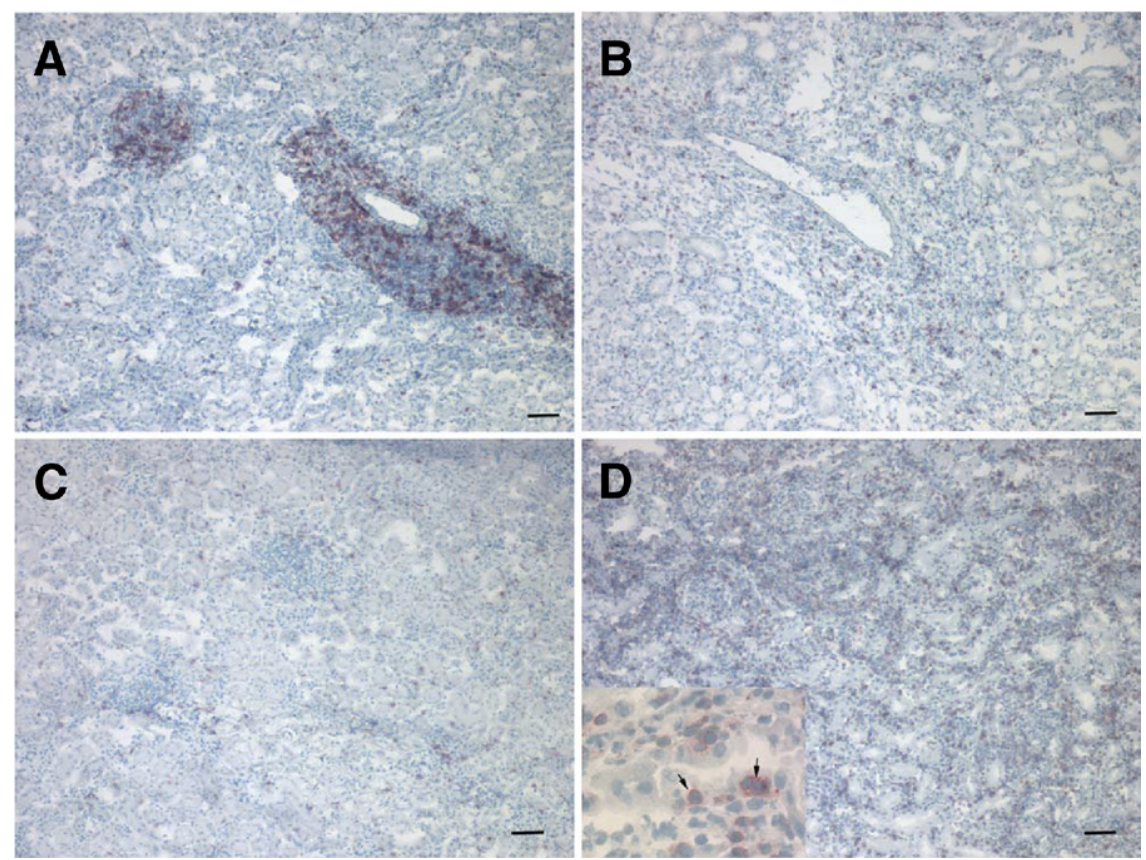

Figure 6. Immunohistochemical stains of $\mathrm{DBA} / 2$ renal allografts for CD4 (A and $\mathbf{B})$ and $\mathrm{CD} 8(\mathbf{C}$ and D). $\mathbf{A}$ and $\mathbf{C}$ : The DT-treated control B6WT recipient 26 days after transplantation. A: The periarterial sheath is primarily $\mathrm{CD} 4^{+}$cells, with few $\mathrm{CD}^{+}$ cells $(\mathbf{C})$; few $\mathrm{CD}^{+}$or $\mathrm{CD}^{+}$cells infiltrate the cortex. $\mathbf{B}$ and $\mathbf{D}$ : The DT-treated B6.Foxp $3^{\text {DTR }}$ recipient 35 days after transplantation. B: The periarterial lymphoid sheath is barely discernible and contains few $\mathrm{CD} 4^{+}$cells, which are found diffusely in the cortex. C: Control. D: An intense and diffuse $\mathrm{CD}^{+}$cell infiltrate is present in the cortex, in contrast to the control (C). Inset: Tubulitis with $\mathrm{CD}^{+}$cells in tubules (arrow). Scale bars: $500 \mu \mathrm{m}$. Similar results were seen in the other recipients in these groups. 


\section{IFN $\gamma$ Reactive T Cell Clones $/ 10^{6}$ Cells}

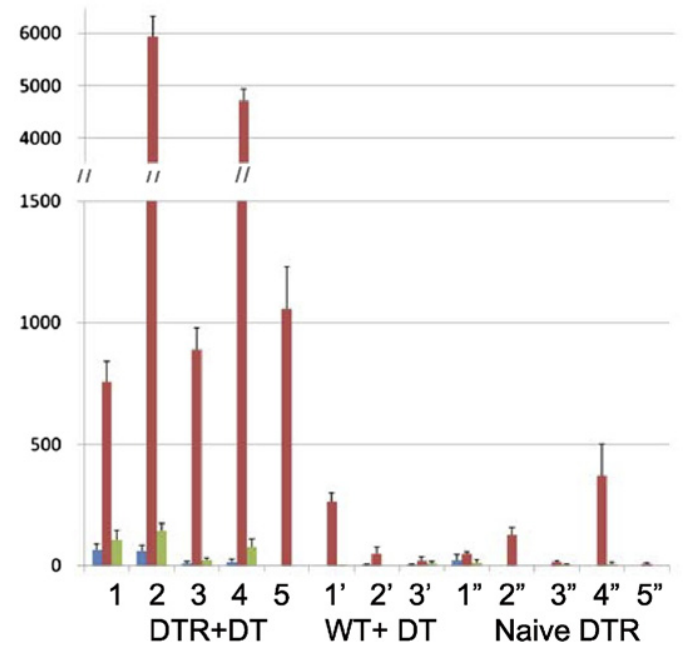

Figure 7. ELISPOT assays of direct reactivity to splenic $\mathrm{T}$ cells from donor $(\mathrm{DBA} / 2)$ or self (B6) at 24 hours. Results are mean \pm SD IFN- $\gamma$-reactive clones $/ 10^{6} \mathrm{~T}$ cells. A strong response to allo (DBA/2), but not to self, is evident in the five B6.Foxp $3^{\mathrm{DTR}}$ recipients of a DBA/2 renal allograft treated with DT (DTR+DT). Little or no allo- or self-reactive response is seen in three stable B6 WT with DBA/2 renal allografts given DT (WT+DT) or five untreated naïve B6.Foxp $3^{\text {DTR }}$ mice (Naïve DTR 1). Stimulators: blue bar, tissue culture medium; red bar, DBA/2; green bar, B6 (self). Data are given as the mean $\pm \mathrm{SD}$ of triplicate from each experiment, grouped by animal number.

remained almost exclusively (>90\%) in the remnants of the nodular aggregates (data not shown). The C4d was detected in the peritubular capillaries in $100 \%$ of the allografts and was not appreciably different from control allografts. Other features indicating acute humoral rejection (neutrophils, thrombi, and fibrinoid necrosis) were not seen.

\section{Pathological Features of Other Organs after Foxp3 Depletion}

Quantitation was performed for splenic Foxp3 ${ }^{+}$cells at 6 to 7 days after DT, which revealed marked loss (18.6 \pm 1.2 Foxp3 $^{+}$cells $/ \mathrm{mm}^{2}$ ) compared with controls (443.3 \pm 130.3 Foxp3 ${ }^{+}$cells $\left./ \mathrm{mm}^{2}\right)(P<0.02$, Mann-Whitney $U$ test). This change is similar to that in the allografts taken at the same time (96\% vs 95\% depletion). Reactive changes were evident in the spleen and lymph nodes at 6 to 7 days after DT in most B6.Foxp3 ${ }^{\text {DTR }}$ recipients, with expansion of white pulp, increased cellularity of red pulp, and expansion of germinal centers. Focal lymphoid infiltrates were found in the pancreas of three of six recipients of allografts and in three of four recipients of isografts (data not shown). Focal lymphoid aggregates were also commonly present in the sinusoids of the liver, involving less than five percent of the samples. One recipient had focal submandibular gland sialadenitis. No abnormality was observed in other organs.

\section{Circulating Alloantibody}

Flow cytometric tests for donor-specific antibody before DT treatment revealed that $73 \%$ of the allograft recipients had detectable anti-donor antibody ( $>2$ SDs above the mean level in isograft recipients). However, the mean level of antibody did not change significantly after DT administration in the seven B6.Foxp $3^{\mathrm{DTR}}$ recipients or the four WT controls studied. The presence of C4d deposition in peritubular capillaries correlated with the level of alloantibody detected (MFC, $12.3 \pm 3.8$ vs $6.0 \pm 1.3$ in the $\mathrm{C}_{4} \mathrm{~d}^{+}$vs the $\mathrm{C} 4 \mathrm{~d}^{-}$recipients; $P<0.01$, two-tailed t-test).

\section{Recipient T-Cell Reactivity}

Splenic T cells were tested for donor reactivity and selfreactivity using ELISPOT assays for IFN- $\gamma$ production (Figure 7). Control B6.Foxp3 ${ }^{\mathrm{DTR}}$ mice not given DT with accepted DBA/2 renal allografts or B6 WT recipients of DBA/2 allografts had little or no T-cell direct reactivity to DBA/2 or self. However, B6.Foxp3 ${ }^{\text {DTR }}$ mice with DBA/2 grafts given DT showed a significant increase in anti$\mathrm{DBA} / 2$ response, with little change in self-reactivity.

\section{Maturation of Dendritic Cells in Spleen and Graft}

Previous studies ${ }^{14}$ showed that Foxp3 depletion by daily doses of DT over 7 days increased the number of DCs in
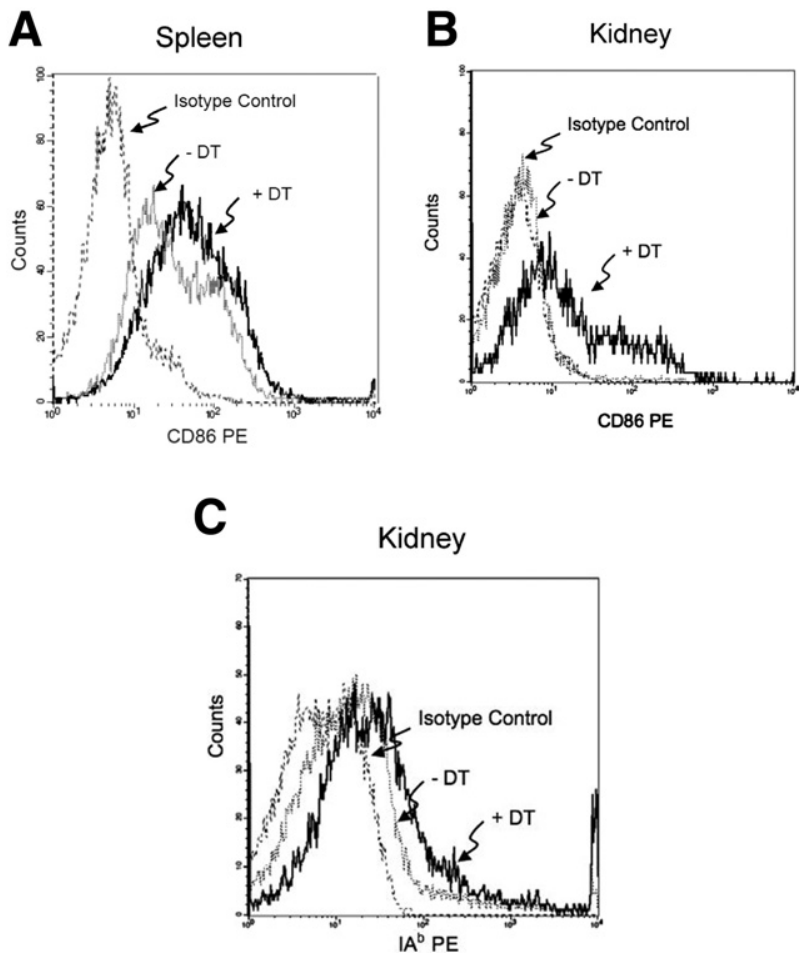

Figure 8. Depletion of regulatory $\mathrm{T}$ cells results in the expression of maturation markers CD86 and $\mathrm{IA}^{\mathrm{b}}$ on $\mathrm{CD} 11 \mathrm{c}^{+}$dendritic cells isolated from the spleen (A) and kidney (B and $\mathbf{C})$. The $\mathrm{CD}_{11 \mathrm{c}^{+}}$cells were purified from two B6.Foxp $3^{\text {DTR }}$ mice treated with $50 \mu \mathrm{g} / \mathrm{kg}$ of DT and two untreated B6.Foxp $3^{\text {DTR }}$ mice, as described in the text (Materials and Methods). Cells were stained for surface expression of CD86 or IA ${ }^{\mathrm{b}}$. Dotted lines indicate isotype control; dashed lines, $\mathrm{CD} 11 \mathrm{c}^{+}$cells isolated from untreated mice; and solid lines, CD $11 \mathrm{c}^{+}$cells isolated from DT-treated mice. The data represent purified splenic or kidney CD $11 \mathrm{c}^{+}$cells, pooled from two mice. In both the spleen (A) and the kidney (B), DCs expressed a higher density of CD86 after Foxp3 depletion. Increased $\mathrm{IA}^{\mathrm{b}}$ was also seen in the kidney DCs $(\mathbf{C})$ and the spleen (data not shown). Similar results were obtained in two experiments. 
the spleen and accelerated their maturation, suggesting that Tregs control T-cell activation by suppression of DC activation. Therefore, we sought evidence for this mechanism in mice treated with our standard regimen with fewer doses of DT. The CD11 ${ }^{+}$spleen cells from naïve B6.Foxp3 ${ }^{\text {DTR }}$ mice given two doses of DT 6 and 7 days previously showed a $17 \%$ increase in the expression of CD86, a DC maturation marker (Figure 8), and CD40 and CD80 (data not shown). The CD11 $\mathrm{c}^{+}$cells isolated from normal kidneys also showed an increase in expression of CD86 and IA ${ }^{\mathrm{b}}$ after Foxp3 depletion compared with untreated controls (Figure $8, \mathrm{~B}$ and $\mathrm{C}$ ).

To determine whether similar increased DC maturation occurs in situ, allograft sections were stained for CD11c and CD86 using two-color fluorescence probes assessed by using morphometric analysis of images obtained by a whole-slide digital fluorescence scanner (Figure 9, A and B). The Foxp3-depleted allografts showed a fourfold increase in CD11c ${ }^{+}$density $\left(201 \pm 57 \times 10^{3}\right.$ pixels $\left./ \mathrm{mm}^{2}\right)$ compared with untreated allografts $\left(45 \pm 48 \times 10^{3}\right.$ pixels $/ \mathrm{mm}^{2}$ ) and a sevenfold increase in $\mathrm{CD} 11 \mathrm{c}^{+} \mathrm{CD} 86^{+}$ double-positive area vs untreated allografts $(70 \pm 46 \times$ $10^{3}$ vs $9 \pm 9 \times 10^{3}$ pixels $/ \mathrm{mm}^{2}$ ) (Figure 9B: $P<0.01$ F-test; and $P<0.003$, Mann-Whitney U-test). More CD86 was expressed by $\mathrm{CD}_{11 \mathrm{C}^{+}}$cells, as judged by an increased percentage of colocalized pixels (Figure 9B) and illustrated in individual DCs in Figure 9A.
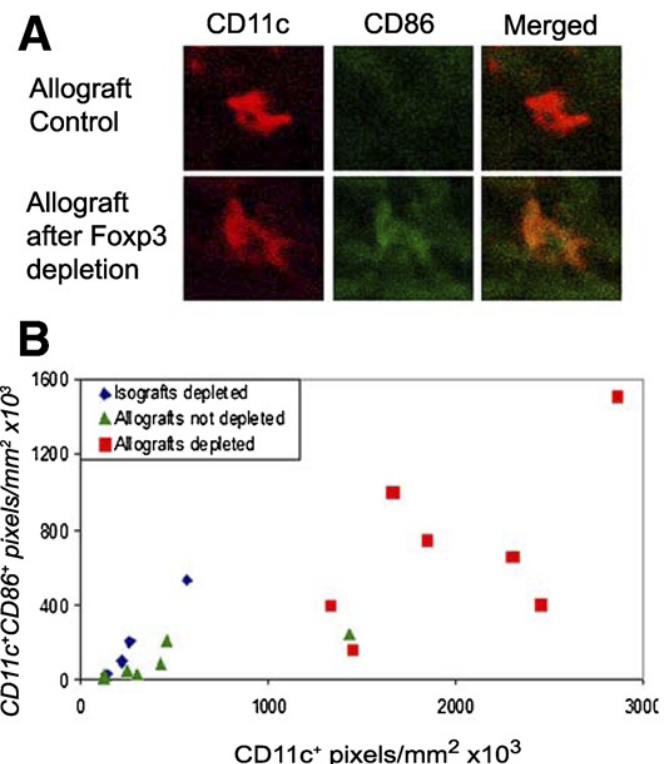

Figure 9. DBA $/ 2$ to B6.Foxp $3^{\text {DTR }}$ renal allografts have increased numbers of DCs with markers of maturity after Foxp3 depletion. Cryostat sections of renal allografts were stained with antibodies against CD11c (Cy3) and CD86 (FITC) and imaged by whole slide fluorescent scanning. A: Representative DCs from DBA/2 to B6.Foxp $3^{\text {DTR }}$ allografts without treatment and 7 days after DT treatment (original power x 400). B: Plot of expression of CD11c vs. co-expression of CD11c and CD86 per $\mathrm{mm}^{2}$ in renal grafts listed in Table 1 (Materials and Methods) plotted by groups (see legend; depleted refers to DT treated B6.Foxp $3^{\text {DTR }}$ recipients). Both overall CD $11 \mathrm{c}^{+}$cells as well as $\mathrm{CD} 11 \mathrm{c}^{+} \mathrm{CD}_{86}{ }^{+}$double positive cells were significantly increased in DT treated allografts, as compared to control allografts $(P<0.01$, F-test). In addition the fraction of $\mathrm{CD} 11 \mathrm{c}^{+}$cells expressing CD86 was also higher in Foxp3 depleted recipients: $33.9 \% \pm 18.2 \%$ of $\mathrm{CD}_{11 \mathrm{c}^{+}}$pixels in Foxp 3 depleted allografts were also $\mathrm{CD} 6^{+}$positive, as compared to $18.8 \% \pm 11.8 \%$ double-positive pixels in Foxp3 depleted allografts $(P<0.05$ by one-tailed $t$-test; 0.055 by Mann Whitney $U$ test)

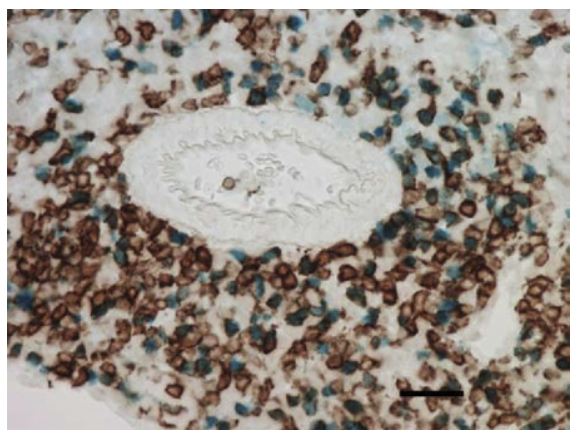

Figure 10. Accepted DBA/2 renal allograft in a CCR4-deficient recipient 111 days after transplantation shows prominent Foxp3 infiltrate in TOLS, similar to that in CCR4-sufficient recipients. Infiltration of Foxp $3^{+}$cells and graft acceptance are not dependent on CCR4, in contrast to heart allografts. Scale bar $=40 \mu \mathrm{m}$.

\section{Foxp3 Cell Infiltration and Acceptance Does Not Depend on CCR4}

Most Foxp3 cells outside lymphoid organs in mice express CCR4, the chemokine receptor for chemokine ligand (CCL) 17 and CCL22. ${ }^{23}$ The CCR4-deficient mice are resistant to tolerance induction to heart allografts and show decreased Foxp3 infiltration in the grafts. ${ }^{24}$ Furthermore, CCR4-deficient Tregs have diminished trafficking to skin and lungs. ${ }^{23}$ To test whether CCR4 was required for infiltration of Foxp3 ${ }^{+}$cells into the kidney and graft acceptance, we transplanted DBA/2 kidneys into CCR4deficient $\mathrm{B} 6$ recipients. All four recipients maintained a stable normal BUN during the observation period of 33 , 86 , 104, or 111 days (BUN: 30, 29, 34, and $48 \mathrm{mg} / \mathrm{dL}$, respectively). Histological examination revealed well-developed TOLS with a similar density of Foxp3 cells and non-Foxp3 T cells, indistinguishable from those in CCR4sufficient B6 recipients (Figure 10). Thus, it appears that other mechanisms than those used to infiltrate heart allografts, skin, and lung are sufficient to attract Foxp3 ${ }^{+}$ cells to TOLS.

\section{Discussion}

The present study shows that spontaneously accepted fully MHC-mismatched allografts are exquisitely sensitive to depletion of Foxp3 ${ }^{+}$cells. It is notable that Foxp3 depletion triggered graft rejection, since many Foxp3independent mechanisms of immune regulation have been identified, including Tr1, Th3 and B cells. ${ }^{25-29}$ These other mechanisms apparently are inactive or insufficient on their own to prevent rejection of murine kidneys. Depletion of Foxp $3^{+}$cells rapidly led to graft dysfunction and markedly altered the graft pathological features, which changed from a periarterial sheath of primarily $\mathrm{CD}^{+}{ }^{+}$Iymphocytes, rich in $\mathrm{Foxp}^{+}$cells, to a diffuse $\mathrm{T}$-cell infiltrate of $\mathrm{CD}^{+}{ }^{+}$and $\mathrm{CD}^{+}$cells in the cortex with tubulitis and endarteritis. These results are consistent with previous reports ${ }^{3,5}$ that showed that donor-reactive effector $T$ cells and alloantibody production exist in this setting but are not able to mediate rejection because of transforming growth factor- $\beta$-mediated 
regulation. Prior studies ${ }^{6,7}$ had drawn attention to Foxp3 ${ }^{+}$ cells in accepted mouse kidney allografts; however, paradoxically, Foxp3 cells were also present during acute rejection in mice and humans and did not correlate with outcome. ${ }^{30,31}$ Therefore, whether Foxp3 ${ }^{+}$cells were immunologically active in promoting acceptance was not clear. In fact, some researchers ${ }^{31}$ have argued that Foxp $3^{+}$cells are not involved in allorecognition but are part of the general inflammatory response.

The mechanisms for spontaneous acceptance reside in properties of the living kidney because kidney slices do not confer tolerance and hearts in the same strain combinations are rejected. ${ }^{3,5-7}$ The organ-specific tolerogenic capacity of kidneys has been described in pigs, in which kidneys, but not hearts, can be accepted longterm; an allograft kidney enables long-term survival of a heart from the same strain. ${ }^{32}$ The continued presence of the kidney allograft is necessary, suggesting that the immunoregulatory mechanisms arise from events in the kidney itself. Donor-specific immunoregulatory CD25+ cells have been detected in the circulation, ${ }^{33}$ and the cells responsible in the kidney are radiation sensitive. ${ }^{32}$

One feature found in accepted kidney allografts not seen in heart allografts is the periarterial lymphoid sheaths containing Foxp3 ${ }^{+}$cells (TOLS), ${ }^{6,34}$ In contrast to heart allografts ${ }^{24}$ and lymph nodes, ${ }^{23}$ infiltration of $\mathrm{Foxp}^{+}$cells in the kidney was not dependent on CCR4, arguing that different mechanisms are responsible for recruitment of $\mathrm{Foxp}^{+}$cells into TOLS. The TOLS are superficially similar to the periarterial lymphoid sheaths in the spleen. However, in contrast to periarterial lymphoid sheaths, TOLS have fewer CD8 cells and B cells are not confined to their periphery. The TOLS also differ from tertiary lymphoid organs, as described in chronically rejected mouse heart grafts and human renal allografts; in their lack of separate B-and T-cell areas; and in their lack of germinal centers. ${ }^{35-37}$ The tertiary lymphoid organs also lack MECA-79+ vessels, a marker of high endothelial venules characteristic of tertiary lymphoid organs (E. A. Farkash, unpublished data). The TOLS also differ from tertiary lymphoid organs produced in the kidney by ectopic expression of lymphotoxin, in that the latter are primarily subcapsular and have germinal centers. ${ }^{38}$ Similar Foxp3-rich structures have been noted in renal biopsy specimens from patients, including operationally tolerant patients receiving the mixed-chimerism protocol ${ }^{1}$ (R. B. Colvin, unpublished data) and in other patients with accepted grafts. ${ }^{39}$ In protocol biopsy specimens from patients undergoing conventional immunosuppression, nodular infiltrates with lymphatic vessels are associated with better graft outcome. ${ }^{40}$

The present studies indicate that Foxp $3^{+}$cells are necessary for the maintenance of TOLS and for continued graft acceptance but do not establish that the TOLS per se are responsible for graft acceptance. Components of graft rejection appear to be present: alloantibody is produced, the graft has an infiltrate, a few had endarteritis, and T-effector cells can be isolated from the recipient. Indeed, in mice, renal allografts may go through a transient state that resembles (or may be) acute rejection. This process usually, but not always, spontaneously sub- sides and graft function returns. ${ }^{3}$ Thus, in the early phase, a peaceful balance of forces, an entente cordiale, appears to develop, rather than elimination of donorreactive clones. The present results suggest that if the balance of forces can be tipped in favor of Tregs, long-term graft acceptance would be promoted. Further studies are needed to determine whether this or other mechanisms are relevant to acceptance of longterm allografts ${ }^{5,6}$ and whether the Tregs in the graft are relevant.

We obtained evidence of one mechanism by which Foxp $3^{+}$cell depletion may promote acute rejection, through accelerated DC maturation and increased recruitment of DCs in the graft. After Foxp $3^{+}$cell depletion, increased expression levels of the costimulatory molecule, CD86, and IA ${ }^{\mathrm{b}}$ were present on $\mathrm{CD}_{11 \mathrm{C}^{+}}$cells isolated from the spleen and kidneys and increased num-

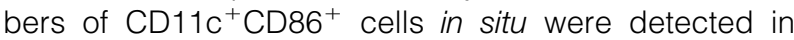
rejected allografts. Others have shown that DCs exhibit increased synthesis of CXCL10, CCL2, and CXCL9 after Foxp3 depletion ${ }^{41}$; and that increased expression of CD86 and MHC II by kidney DCs is associated with increased production of tumor necrosis factor- $\alpha$ and IL$6{ }^{42}$ These responses would be expected to lead to increased effectiveness of alloantigen presentation in lymphoid organs and in the graft itself. ${ }^{43}$ Although our experiments have not directly proved enhanced antigen presentation by DCs, our observations are consistent with the postulated mechanism by which Tregs are thought to control autoimmunity by inhibition of DC activation. ${ }^{14,44}$ Enhanced DC maturation would be expected to promote alloreactivity; indeed, after Foxp3 depletion, markedly increased donor reactivity was detected by ELISPOT assays, with only a minor effect on self-reactivity. Further evidence that DCs are critical in the process of acceptance comes from the demonstration that the expression of Toll-IL-1R8 in kidney DCs is necessary for the promotion of graft acceptance in mice; the process involves the generation of Tregs. ${ }^{45}$

These results do not prove that DC maturation is the mechanism nor do they exclude other documented modes of action of Tregs, such as interference with access of naïve $T$ cells to $\mathrm{DCs}^{46,47}$ or a direct inhibitory effect on other T cells via transforming growth factor $\beta .{ }^{48}$ These experiments also do not exclude other, nonFoxp3-dependent, mechanisms for graft acceptance after 3 months, in which there is evidence for non-Treg mechanisms. ${ }^{6}$ Further studies will be needed to address these alternatives.

We considered the possibility that alloantibodies play a role in the rejection triggered by depletion of $\mathrm{Foxp}^{+}$ cells. Previous studies ${ }^{3,5}$ have shown that mice with accepted renal allografts produce cytotoxic donor-specific antibody transiently, without adverse effects on the graft. In the present studies, most recipients with accepted grafts had donor-reactive alloantibodies and C4d deposition in the graft microcirculation, indicating local complement fixation with apparent accommodation. The level of antibody did not change significantly after Foxp3 depletion nor did the grafts develop any other features typical of antibody-mediated rejection, such as neutrophil 
infiltration or glomerulitis. B cells also showed no appreciable change in number or distribution in the graft. Thus, we believe it unlikely that antibody mediated the rejection observed.

We were concerned that autoimmune disease might be a limiting factor in these studies because severe enteritis and a wasting disease occurs in Foxp3 $3^{\text {DTR }}$ mice after daily doses of DT over 2 to 3 weeks, ${ }^{13,14}$ similar to that in scurfy mice. ${ }^{49-51}$ However, we observed no weight loss or other sign of severe autoimmune disease in these experiments. Although we cannot exclude a minor contribution of autoimmunity to the observed precipitation of allograft rejection, we believe that it is unlikely to be a major factor because the inflammation in other organs was focal; rejection developed in all recipients, whether histological lesions were seen in other organs; inflammation was not precipitated in isografts or native kidneys; and minimal or no autoreactivity was detected by ELISPOT analysis.

These studies establish the DT-Foxp3 ${ }^{\text {DTR }}$ system developed by Rudensky as a useful platform for evaluating the contribution and mechanisms of action of $\mathrm{Foxp}^{+}$ cells in allograft acceptance. ${ }^{14}$ The DT is highly selective and is able to deplete Foxp $3^{+}$cells from lymphoid organs and the graft. With the limited dose used herein, depletion is transient but almost complete and is not complicated by any obvious ill effects.

The induction of tolerance to MHC-mismatched allografts has moved closer to reality with the publication of successful drug-free survival of a small cohort of patients treated with the mixed-chimerism protocol. ${ }^{1}$ However, many problems remain before this approach can be widely applied; further understanding of the mechanisms and markers of graft acceptance is needed. Because lymphoid infiltrates are present in both rejected and accepted grafts, ${ }^{40,52,53}$ distinguishing these states in the graft will be important for monitoring outcomes and evaluating therapy and may provide insights into mechanisms of acceptance.

\section{Acknowledgments}

We thank Alexander Y. Rudensky, Ph.D. (Memorial SloanKettering Cancer Center, New York, NY), for providing the B6.Foxp3 ${ }^{\text {DTR }}$ mice; Andrew D. Luster, M.D., Ph.D. (Massachusetts General Hospital, Boston, MA), for providing the CCR4-deficient mice; Nicole Brousaides, B.A., Divya Sebastian, B.S., and Catherine Adams, B.A., for providing excellent technical assistance; and Yukako Yagi, M.D., for providing assistance with fluorescent slide scanning.

\section{References}

1. Kawai T, Cosimi AB, Spitzer TR, Tolkoff-Rubin N, Suthanthiran M, Saidman SL, Shaffer J, Preffer FI, Ding R, Sharma V, Fishman JA, Dey B, Ko DS, Hertl M, Goes NB, Wong W, Williams WW Jr, Colvin RB, Sykes M, Sachs DH: HLA-mismatched renal transplantation without maintenance immunosuppression. N Engl J Med 2008, 358:353-361

2. Newell KA, Asare A, Kirk AD, Gisler TD, Bourcier K, Suthanthiran M, Burlingham WJ, Marks WH, Sanz I, Lechler RI, Hernandez-Fuentes
MP, Turka LA, Seyfert-Margolis VL; Immune Tolerance Network ST507 Study Group: Identification of a B cell signature associated with renal transplant tolerance in humans. J Clin Invest 2010, 120:1836-1847

3. Russell PS, Chase CM, Colvin RB, Plate JM: Kidney transplants in mice: an analysis of the immune status of mice bearing long-term, $\mathrm{H}-2$ incompatible transplants. J Exp Med 1978, 147:1449-1468

4. Russell PS, Chase CM, Colvin RB, Plate JM: Induced immune destruction of long-surviving, $\mathrm{H}-2$ incompatible kidney transplants in mice. J Exp Med 1978, 147:1469-1486

5. Bickerstaff AA, Wang JJ, Pelletier RP, Orosz CG: Murine renal allografts: spontaneous acceptance is associated with regulated $T$ cell-mediated immunity. J Immunol 2001, 167:4821-4827

6. Cook CH, Bickerstaff AA, Wang JJ, Nadasdy T, Della Pelle P, Colvin RB, Orosz CG: Spontaneous renal allograft acceptance associated with "regulatory" dendritic cells and IDO. J Immunol 2008, 180:3103-3112

7. Brown K, Moxham V, Karegli J, Phillips R, Sacks SH, Wong W: Ultra-localization of Foxp3+ T cells within renal allografts shows infiltration of tubules mimicking rejection. Am J Pathol 2007, 171: 1915-1922

8. Zheng SG, Meng L, Wang JH, Watanabe M, Barr ML, Cramer DV, Gray JD, Horwitz DA: Transfer of regulatory T cells generated ex vivo modifies graft rejection through induction of tolerogenic CD4+CD25+ cells in the recipient. Int Immunol 2006, 18:279-289

9. Graca L, Cobbold SP, Waldmann H: Identification of regulatory T cells in tolerated allografts. J Exp Med 2002, 195:1641-1646

10. Joffre O, Santolaria T, Calise D, AI Saati T, Hudrisier D, Romagnoli P, van Meerwijk JP: Prevention of acute and chronic allograft rejection with $\mathrm{CD} 4+\mathrm{CD} 25+$ Foxp3+ regulatory $\mathrm{T}$ lymphocytes. Nature Med 2008, 14:88-92

11. Fehr $\mathrm{T}$, Takeuchi $\mathrm{Y}$, Kurtz J, Wekerle $\mathrm{T}$, Sykes $\mathrm{M}$ : Early regulation of CD8 $T$ cell alloreactivity by CD4+CD25- T cells in recipients of anti-CD154 antibody and allogeneic BMT is followed by rapid peripheral deletion of donor-reactive CD8+ T cells, precluding a role for sustained regulation. Eur J Immunol 2005, 35:2679-2690

12. Allakhverdi Z, Fitzpatrick D, Boisvert A, Baba N, Bouguermouh S, Sarfati M, Delespesse G: Expression of CD103 identifies human regulatory T-cell subsets. J Allergy Clin Immunol 2006, 118:1342-1349

13. Lahl K, Loddenkemper C, Drouin C, Freyer J, Arnason J, Eberl G, Hamann A, Wagner H, Huehn J, Sparwasser T: Selective depletion of Foxp3+ regulatory T cells induces a scurfy-like disease. J Exp Med 2007, 204:57-63

14. Kim JM, Rasmussen JP, Rudensky AY: Regulatory T cells prevent catastrophic autoimmunity throughout the lifespan of mice. Nat Immunol 2007, 8:191-197

15. Couper KN, Blount DG, de Souza JB, Suffia I, Belkaid Y, Riley EM: Incomplete depletion and rapid regeneration of Foxp3+ regulatory $T$ cells following anti-CD25 treatment in malaria-infected mice. J Immunol 2007, 178:4136-4146

16. Benghiat FS, Graca L, Braun MY, Detienne S, Moore F, Buonocore S, Flamand V, Waldmann H, Goldman M, Le Moine A: Critical influence of natural regulatory CD25+ T cells on the fate of allografts in the absence of immunosuppression. Transplantation 2005, 79:648-654

17. Li W, Carper K, Liang Y, Zheng XX, Kuhr CS, Reyes JD, Perkins DL, Thomson AW, Perkins JD: Anti-CD25 mAb administration prevents spontaneous liver transplant tolerance. Transplant Proc 2006, 38: 3207-3208

18. Yuan Q, Bromley SK, Means TK, Jones KJ, Hayashi F, Bhan AK, Luster AD: CCR4-dependent regulatory $T$ cell function in inflammatory bowel disease. J Exp Med 2007, 204:1327-1334

19. Solez K, Colvin RB, Racusen LC, Haas M, Sis B, Mengel M, Halloran PF, Baldwin W, Banfi G, Collins AB, Cosio F, David DS, Drachenberg C, Einecke G, Fogo AB, Gibson IW, Glotz D, Iskandar SS, Kraus E, Lerut E, Mannon RB, Mihatsch M, Nankivell BJ, Nickeleit V, Papadimitriou JC, Randhawa P, Regele H, Renaudin K, Roberts I, Seron D, Smith RN, Valente M: Banff 07 classification of renal allograft pathology: updates and future directions. Am J Transplant 2008, 8:753-760

20. Uehara S, Chase CM, Cornell LD, Madsen JC, Russell PS, Colvin RB: Chronic cardiac transplant arteriopathy in mice: relationship of alloantibody, C4d deposition and neointimal fibrosis. Am J Transplant 2007 7:57-65 
21. Mannon RB, Kotzin BL, Nataraj C, Ferri K, Roper E, Kurlander RJ, Coffman TM: Downregulation of T cell receptor expression by CD8(+) Iymphocytes in kidney allografts. J Clin Invest 1998, 101:2517-2527

22. Boskovic S, Kawai T, Smith RN, Wee SL, Nadazdin O, Koyama I, Saidman S, Cardarelli F, Elias N, Sykes M, Strom T, Colvin RB, Sachs $\mathrm{DH}$, Cosimi AB: Monitoring antidonor alloantibodies as a predictive assay for renal allograft tolerance/long-term observations in nonhuman primates. Transplantation 2006, 82:819-825

23. Sather BD, Treuting P, Perdue N, Miazgowicz M, Fontenot JD, Rudensky AY, Campbell DJ: Altering the distribution of Foxp3 $(+)$ regulatory $\mathrm{T}$ cells results in tissue-specific inflammatory disease. J Exp Med 2007, 204:1335-1347

24. Lee I, Wang L, Wells AD, Dorf ME, Ozkaynak E, Hancock WW: Recruitment of Foxp3 $+\mathrm{T}$ regulatory cells mediating allograft tolerance depends on the CCR4 chemokine receptor. J Exp Med 2005 201:1037-1044

25. Cottrez F, Groux H: Specialization in tolerance: innate $\mathrm{CD}(4+) \mathrm{CD}(25+)$ versus acquired $\mathrm{TR} 1$ and $\mathrm{TH} 3$ regulatory $\mathrm{T}$ cells. Transplantation 2004, 77:S12-S15

26. Chen C, Lee WH, Yun P, Snow P, Liu CP: Induction of autoantigenspecific Th2 and $\operatorname{Tr} 1$ regulatory $T$ cells and modulation of autoimmune diabetes. J Immunol 2003, 171:733-744

27. Jiang S, Lechler RI, He XS, Huang JF: Regulatory T cells and transplantation tolerance. Hum Immunol 2006, 67:765-776

28. Dugast AS, Vanhove B: Immune regulation by non-lymphoid cells in transplantation. Clin Exp Immunol 2009, 156:25-34

29. Mizoguchi A, Bhan AK: A case for regulatory B cells. J Immunol 2006, 176:705-710

30. Veronese F, Rotman S, Smith RN, Pelle TD, Farrell ML, Kawai T, Benedict Cosimi A, Colvin RB: Pathological and clinical correlates of FOXP3 $(+)$ cells in renal allografts during acute rejection. Am J Transplant 2007, 7:914-922

31. Bunnag S, Allanach K, Jhangri GS, Sis B, Einecke G, Mengel M, Mueller TF, Halloran PF: FOXP3 expression in human kidney transplant biopsies is associated with rejection and time post transplant but not with favorable outcomes. Am J Transplant 2008, 8:1423-1433

32. Mezrich JD, Yamada K, Lee RS, Mawulawde K, Benjamin LC, Schwarze ML, Maloney ME, Amoah HC, Houser SL, Sachs DH, Madsen JC: Induction of tolerance to heart transplants by simultaneous cotransplantation of donor kidneys may depend on a radiationsensitive renal-cell population. Transplantation 2003, 76:625-631

33. Mezrich JD, Kesselheim JA, Johnston DR, Yamada K, Sachs DH, Madsen JC: The role of regulatory cells in miniature swine rendered tolerant to cardiac allografts by donor kidney cotransplantation. Am J Transplant 2003, 3:1107-1115

34. Cook $\mathrm{CH}$, Bickerstaff AA, Wang JJ, Zimmerman PD, Forster MR Nadasdy T, Colvin RB, Hadley GA, Orosz CG: Disruption of murine cardiac allograft acceptance by latent cytomegalovirus. Am J Transplant 2009, 9:42-53

35. Thaunat O, Patey N, Caligiuri G, Gautreau C, Mamani-Matsuda M, Mekki Y, Dieu-Nosjean MC, Eberl G, Ecochard R, Michel JB, GraffDubois S, Nicoletti A: Chronic rejection triggers the development of an aggressive intragraft immune response through recapitulation of lymphoid organogenesis. J Immunol 2010, 185:717-728

36. Baddoura FK, Nasr IW, Wrobel B, Li Q, Ruddle NH, Lakkis FG: Lymphoid neogenesis in murine cardiac allografts undergoing chronic rejection. Am J Transplant 2005, 5:510-516

37. Aloisi F, Pujol-Borrell R: Lymphoid neogenesis in chronic inflammatory diseases. Nat Rev Immunol 2006, 6:205-217
38. Kratz A, Campos-Neto A, Hanson MS, Ruddle NH: Chronic inflammation caused by lymphotoxin is lymphoid neogenesis. J Exp Med 1996, 183:1461-1472

39. Xu Q, Lee J, Jankowska-Gan E, Schultz J, Roenneburg DA, Haynes LD, Kusaka S, Sollinger HW, Knechtle SJ, VanBuskirk AM, Torrealba JR, Burlingham WJ: Human CD4+CD25low adaptive T regulatory cells suppress delayed-type hypersensitivity during transplant tolerance. J Immunol 2007, 178:3983-3995

40. Stuht S, Gwinner W, Franz I, Schwarz A, Jonigk D, Kreipe $H$, Kerjaschki D, Haller $H$, Mengel M: Lymphatic neoangiogenesis in human renal allografts: results from sequential protocol biopsies. Am J Transplant 2007, 7:377-384

41. Lund JM, Hsing L, Pham TT, Rudensky AY: Coordination of early protective immunity to viral infection by regulatory $T$ cells. Science 2008, 320:1220-1224

42. Cho WY, Choi HM, Lee SY, Kim MG, Kim HK, Jo SK: The role of Tregs and $\mathrm{CD} 11 \mathrm{c}(+)$ macrophages/dendritic cells in ischemic preconditioning of the kidney. Kidney Int 2010, 78:981-992

43. Steinman RM, Idoyaga J: Features of the dendritic cell lineage. Immunol Rev 2010, 234:5-17

44. Liu K, Victora GD, Schwickert TA, Guermonprez P, Meredith MM, Yao K, Chu FF, Randolph GJ, Rudensky AY, Nussenzweig M: In vivo analysis of dendritic cell development and homeostasis. Science 2009, 324:392-397

45. Noris M, Cassis P, Azzollini N, Cavinato R, Cugini D, Casiraghi F, Aiello S, Solini S, Cassis L, Mister M, Todeschini M, Abbate M, Benigni A, Trionfini P, Tomasoni S, Mele C, Garlanda C, Polentarutti N, Mantovani A, Remuzzi G: The Toll-IL-1R member Tir8/SIGIRR negatively regulates adaptive immunity against kidney grafts. J Immunol 2009 , 183:4249-4260

46. Mempel TR, Pittet MJ, Khazaie K, Weninger W, Weissleder R, von Boehmer H, von Andrian UH: Regulatory T cells reversibly suppress cytotoxic $\mathrm{T}$ cell function independent of effector differentiation. Immunity 2006, 25:129-141

47. Tang Q, Adams JY, Tooley AJ, Bi M, Fife BT, Serra P, Santamaria P, Locksley RM, Krummel MF, Bluestone JA: Visualizing regulatory T cell control of autoimmune responses in nonobese diabetic mice. Nat Immunol 2006, 7:83-92

48. Andersson J, Tran DQ, Pesu M, Davidson TS, Ramsey H, O'Shea JJ, Shevach EM: CD4+ FoxP3+ regulatory T cells confer infectious tolerance in a TGF-beta-dependent manner. J Exp Med 2008, 205: 1975-1981

49. Godfrey VL, Wilkinson JE, Russell LB: X-linked lymphoreticular disease in the scurfy (sf) mutant mouse. Am J Pathol 1991, 138:1379-1387

50. Lyon MF, Peters J, Glenister PH, Ball S, Wright E: The scurfy mouse mutant has previously unrecognized hematological abnormalities and resembles Wiskott-Aldrich syndrome. Proc Natl Acad Sci U S A 1990, 87:2433-2437

51. Sharma R, Sung SS, Fu SM, Ju ST: Regulation of multi-organ inflammation in the regulatory $T$ cell-deficient scurfy mice. J Biomed Sci 2009, 16:20

52. Shimizu A, Yamada K, Meehan SM, Sachs DH, Colvin RB: Acceptance reaction: intragraft events associated with tolerance to renal allografts in miniature swine. J Am Soc Nephrol 2000, 11:2371-2380

53. Mengel M, Gwinner W, Schwarz A, Bajeski R, Franz I, Brocker V, Becker T, Neipp M, Klempnauer J, Haller $\mathrm{H}$, Kreipe $\mathrm{H}$ : Infiltrates in protocol biopsies from renal allografts. Am J Transplant 2007, 7:356-365 